\title{
Ethylene Production in Spinach Leaves during Floral Induction
}

\author{
M. CREVECOEUR ${ }^{1,3}$, C. PENEL ${ }^{1}, H$. GREPIN $^{1}$ AND TH. GASPAR 2 \\ ${ }^{1}$ Physiologie végétale, Université de Genève, $\mathrm{CH}-1211$ Genève 4, Switzerland \\ ${ }^{2}$ Hormonologie Fondamentale et Appliquée, Institut de Botanique B 22, \\ Université de Liège, Sart Tilman, B-4000 Liège, Belgium
}

Received 17 February 1986

\begin{abstract}
Crevecoeur, M., Penel, C., Greppin, H. and Gaspar, Th 1986. Ethylene production in spınach leaves during floral induction.-J. exp. Bot. 37: 1218-1224.

Spinach plants were induced to flower by transferring them from short days to continuous light. Their leaf laminae released more ethylene than those from vegetative plants. These leaves also exhibited a greater capacity to convert exogenous ACC into ethylene. Cell wall preparations from the leaves of continuously illuminated plants also converted exogenous ACC into ethylene more readily than extracts from short day plants. These effects and also those previously reported for peroxidases appear very similar to these brought about by various environmental stresses such as pollution and mechanical irritation.
\end{abstract}

Key words-Ethylene, floral induction, stress, photoperiod, spinach.

Correspondence to: Laboratoire de Physiologie végétale, Université de Genève, 3, pl de rUniversité, $\mathrm{CH}-1211$ Genève 4, Switzerland.

\section{INTRODUCTION}

'There is little question that ethylene can play a significant role in flower initiation ... Studies of SAM ( $S$-adenosylmethionine) or ACC (1-aminocyclopropane-1-carboxylic acid) biosynthesis and transport in relation to environmental and chemical controls of floral initiation should provide important clues as to how ethylene itself may participate in induction and perhaps evocation...'(Bernier, Kinet, and Sachs, 1981). There are indeed few studies on ethylene metabolism and production in relation to the induction of flowering. Suge (1977) was probably the first to follow endogenous ethylene in relation to flowering. He found that ethylene production increased gradually and then declined in both radish and pea exposed to vernalizing temperature. After return to normal growing temperatures ethylene production was slower in the vernalized than in the non-vernalized plants. These results may help to explain why the absolute requirement of vernalization for the flowering ability of buds of Cichorium intybus can be replaced by an ethylene treatment at room temperature (Joseph, Billot, Soudain, and Come, 1985). It also may explain why ethylene

3 To whom correspondence should be addressed.

Abbreviations: ACC, 1-aminocyclopropane-1-carboxylic acid; AVG, aminoethoxyvinylglycine; CL, continuous light; HEPES, $N$-2-hydrox yethylpiperazine- $N$-2-ethane sulphonic acid; MES, $2-(N$-morpholino)-ethane sulphonic acid; SAM, S-adenosylmethionine; SD, short days; TRIS, $\alpha, \alpha, \alpha$-Tris-(hydroxymethyl)-methylamine.

(C) Oxford University Press 1986 
treatment of tobacco and Pharbitis immediately after an exposure to a floral inductive environment favoured vegetative growth and retarded flowering (Suge, 1974; Kasperbauer and Hamilton, 1978). More recently, De Greef, van Dijck, de Proft, and Mekers (1983) have shown that Aechmea plants can be induced to flower either by ethylene or ACC application but only when such plants reached 'flowering maturity'. Flowering maturity of these plants was precisely correlated with their capacity to convert large amounts of ACC into ethylene. It was also shown that flowering induction of some Bromeliaceae could be retarded by AVG (aminoethoxyvinylglycine), an inhibitor of ethylene biosynthesis (Mekers, de Proft, and Jacobs, 1983).

In order to elucidate further the possible role of ethylene synthesis in the flowering induction process, the extent of ethylene production and the conversion of $\mathrm{ACC}$ to ethylene was examined in the leaves of the long-day plant Spinacia oleracea currently used in our laboratory for the study of flowering (Penel and Greppin, 1974, 1975; Karege, Penel, and Greppin, 1982). From this work it seems that the earliest steps of this process involve fast biophysical and biochemical modifications of cell structures that support vegetative growth (Greppin, Auderset, Bonzon, and Penel, 1978).

\section{MATERIALS AND METHODS \\ Plant material}

Spinach plants (Spinacia oleracea L. cv. Nobel) were grown in a phytotron under standard conditions of illumination ( $100 \mu \mathrm{E} \mathrm{m}^{-2} \mathrm{~s}^{-1}$ provided by Sylvania fluorescent lamps 'daylight', $40 \mathrm{~W}$, Sylvania Electric products, Danvers, Mass., U.S.A.), temperature $\left(21^{\circ} \mathrm{C}\right)$ and humidity $(70 \%$ during the dark, $50 \%$ during the light period).

\section{Photoperiodic treatments}

Three different light treatments were used in order to characterize: (i) the vegetative state (5 weeks in short days of $8 \mathrm{~h}$ light), (ii) the transition to the floral state ( 5 weeks in short days, then transfer in continuous light for $24 \mathrm{~h}$ ), and (iii) the effect of a transfer as in (ii), but with plants already induced by $24 \mathrm{~h}$ continuous illumination but transferred back to short days for $5 \mathrm{~d}$. This treatment is called 'mimicked inductive treatment'.

\section{Sampling}

The two youngest leaves ( 3 and 4) fully expanding at the time of analysis were excised and divided into laminae and petioles.

\section{Ethylene measurements}

Two leaf laminae were dipped by their bases in a $2 \times 10^{-6} \mathrm{~m}^{3}$ glass test tube containing $0.7 \times 10^{-6} \mathrm{~m}^{3}$ $\mathrm{H}_{2} \mathrm{O}$ or ACC $\left(10 \mathrm{~mol} \mathrm{~m}^{-3}\right)$ fixed at the bottom of a $60 \mathrm{~cm}^{3}$ glass bottle hermetically closed with a rubber plug. Petiole segments $20 \mathrm{~mm}$ long were set on a filter paper sheet imbibed either with $\mathrm{H}_{2} \mathrm{O}$ or ACC $(10$ mol m${ }^{-3}$ ) in $35 \times 10^{-6} \mathrm{~m}^{3} \mathrm{glass}$ bottles similarly closed. Whole plants with their four leaves and with their roots (previously rinsed with tap water) were similarly enclosed in $150 \times 10^{-6} \mathrm{~m}^{3}$ bottles ( 1 plant per bottle) in the presence of $\mathrm{H}_{2} \mathrm{O}$ or ACC. Ethylene production was quantified after $24 \mathrm{~h}$ at room temperature by G.C. according to the method used by Boyer, Desbiez, Hofinger, and Gaspar (1983).

\section{Fractionation}

Samples of leaves weighing $10 \mathrm{~g}$ were ground in a precooled mortar in $25 \mathrm{~cm}^{3} \mathrm{~m}^{-3}$ MES buffer containing $500 \mathrm{~mol} \mathrm{~m}^{-3}$ sucrose, and adjusted to $\mathrm{pH} 7 \cdot 2$ with TRIS buffer. After filtration on a nylon cloth, the extract was centrifuged at $3000 \mathrm{~g}$ for $10 \mathrm{~min}$. The supernatant was centrifuged at $6000 \mathrm{~g}$ for $10 \mathrm{~min}$, then at $20000 \mathrm{~g}$ for $30 \mathrm{~min}$. The resulting supernatant and the pellet constituted the soluble and the microsomal fractions respectively. The pellet obtained after the first centrifugation was resuspended in $25 \mathrm{~mol} \mathrm{~m}^{-3} \mathrm{MES}$ buffer (pH 7.2) and centrifuged at $1000 \mathrm{~g}$ for $10 \mathrm{~min}$. This yielded a wall pellet. Both the microsomal and the wall pellets were resuspended in $10 \mathrm{~mol} \mathrm{~m}^{-3} \mathrm{HEPES}$ buffer, $\mathrm{pH} 8 \cdot 2$. Aliquots of the fractions corresponding to $200 \mu \mathrm{g}$ proteins were absorbed onto a filter paper sheet in $35 \times 10^{-6} \mathrm{~m}^{3}$ 
glass bottles in the presence of $\mathrm{ACC}\left(1.0 \mathrm{~mol} \mathrm{~m}^{-3}\right)$ and $\mathrm{MnCl}_{2}\left(0-5 \mathrm{~mol} \mathrm{~m}^{-3}\right)$; ethylene production was measured after $24 \mathrm{~h}$ at room temperature.

\section{ACC content}

Samples $(1.0 \mathrm{~g})$ of leaf lamina or petiole were extracted with $80 \%$ ethanol and centrifuged at $5000 \mathrm{~g}$ for $10 \mathrm{~min}$. The supernatant was evaporated to dryness at $37^{\circ} \mathrm{C}$ and the residue was resuspended in $1 \times 10^{-6} \mathrm{~m}^{3}$ distilled water. Free ACC content was then determined according to Lizada and Yang (1979) from the ethylene evolved after $2 \mathrm{~h}$ from $1.0 \mathrm{~cm}^{3}$ solution containing: $0.8 \times 10^{-6} \mathrm{~m}^{3}$ aqueous extract, sodium hypochlorite $0.44 \%$ (wt./vol.), $\mathrm{HgCl}_{2} 1.0 \mathrm{~mol} \mathrm{~m}^{-3}$ and $3.3 \%(\mathrm{v} / \mathrm{v})$ of a $\mathrm{NaOH}$ saturated solution. This was enclosed in a sealed $35 \mathrm{~cm}^{3}$ glass bottle.

Freshly prepared standards were run routinely. Each experiment was repeated at least four times with different batches of plants.

\section{RESULTS}

Ethylene production by excised laminae of leaves 3 and 4 from vegetative plants (grown under SD) measured at the end of a darkness period was $52 \mu \mathrm{m}^{3} \mathrm{~g}^{-1}$ over $24 \mathrm{~h}$ (Table 1). Leaf laminae from plants that have been induced to flower (by a $24 \mathrm{~h}$ period of continuous light) produced twice as much ethylene. Comparable results were obtained using whole plants instead of excised leaf laminae (Table 1). Further analyses indicated that this increase already was measurable during the first hours following the transfer of SD plants to continuous light. Ethylene production by excised petioles of the same leaves 3 and 4 was quite the same for vegetative and induced plants (Table 1).

When ACC was applied to leaf laminae and to petioles, ethylene production from both vegetative plants and plants induced to flower was increased severalfold (Table 1). The ability of laminae from induced plants to convert exogenous ACC to ethylene was three times greater than that from vegetative plants (Table 1); that of petioles was twice as high (Table 1).

Table 2 indicates that $\mathrm{ACC}$ in the laminae was more concentrated in vegetative plants than that in florally induced plants. However, the ACC content in the petioles was similar in both types of plants.

Laminae of plants which had been induced by $24 \mathrm{~h}$ continuous light and transferred back to short days for $5 \mathrm{~d}$ returned to a rate of ethylene production and ability to convert ACC to ethylene typical of non-induced plants (Table 3). A second inductive treatment of $24 \mathrm{~h}$ continuous illumination at the end of these 5 short days again resulted in the changes mentioned before (Table 3).

T A B LE 1. Ethylene production ( $\mathrm{um}^{3} \mathrm{~g}^{-1}$ over $24 \mathrm{~h}$ ) by excised leaflaminae, petioles and whole vegetative and induced spinach plants in the absence and in the presence of $\left.A C C(10 \mathrm{~mol} \mathrm{~m})^{-3}\right)$. Means of four replicates and standard errors

\begin{tabular}{|c|c|c|}
\hline & $\begin{array}{l}\text { Vegatative plants } \\
\text { (SD) }\end{array}$ & $\begin{array}{l}\text { Induced plants } \\
(\mathrm{SD}+24 \mathrm{~h} \mathrm{CL})\end{array}$ \\
\hline \multicolumn{3}{|l|}{ Leaf laminae } \\
\hline$-\mathrm{ACC}$ & \multirow{2}{*}{$\begin{array}{c}52 \cdot 44 \pm \quad 4 \cdot 32 \\
1217 \quad \pm 204\end{array}$} & \multirow{3}{*}{$\begin{array}{c}113.86 \pm 8.43 \\
3646 \pm 450\end{array}$} \\
\hline$+\mathrm{ACC}$ & & \\
\hline \multicolumn{2}{|l|}{ Whole plants } & \\
\hline$-\mathrm{ACC}$ & \multirow{2}{*}{$\begin{array}{r}13 \cdot 50 \pm \\
82.73 \pm 12.35\end{array}$} & \multirow{2}{*}{$\begin{array}{r}20.32 \pm \quad 4.88 \\
148.97 \pm 21.46\end{array}$} \\
\hline$+\mathrm{ACC}$ & & \\
\hline \multicolumn{3}{|l|}{ Leaf petioles } \\
\hline$-\mathrm{ACC}$ & \multirow{2}{*}{$\begin{array}{r}256.64 \pm 22.57 \\
1198+72.92\end{array}$} & \multirow{2}{*}{$\begin{array}{r}252 \cdot 22 \pm 34 \\
2598 \pm 280\end{array}$} \\
\hline$+\mathrm{ACC}$ & & \\
\hline
\end{tabular}


T A B LE 2. ACC content $\left(10^{-9} \mathrm{~mol} \mathrm{~g}^{-1} \mathrm{fr}\right.$. wt. $)$ in leaf laminae and petioles from vegetative and induced plants

\begin{tabular}{lll}
\hline ACC content in & $\begin{array}{l}\text { Vegetative plants } \\
\text { (SD) }\end{array}$ & $\begin{array}{l}\text { Induced plants } \\
\text { (SD+24 h CL) }\end{array}$ \\
\hline Leaf laminae & $2 \cdot 36 \pm 0-20$ & $1 \cdot 50 \pm 0 \cdot 19$ \\
Petioles & $1 \cdot 12 \pm 0-17$ & $1 \cdot 13 \pm 0 \cdot 18$ \\
\hline
\end{tabular}

Means of four replicates and standard errors.

TABLE 3. Ethylene production $\left(\mathrm{um}^{3} \mathrm{~g}^{-1}\right.$ over $\left.24 \mathrm{~h}\right)$ by excised leaf laminae from plants subjected to various photoperiod sequences

\begin{tabular}{lcl}
\hline Photoperiodic treatments & $\begin{array}{l}\text { Leaf laminae } \\
+\mathrm{H}_{2} \mathrm{O}\end{array}$ & $\begin{array}{l}\text { Leaf laminae } \\
+\mathrm{ACC}\left(10 \mathrm{~mol} \mathrm{~m} \mathrm{~m}^{-3}\right)\end{array}$ \\
\hline 37 SD & $50 \pm 10-78$ & $1287 \pm 170$ \\
$36 \mathrm{SD}+24 \mathrm{~h} \mathrm{CL}$ & $94 \pm 12 \cdot 58$ & $4505 \pm 380$ \\
$31 \mathrm{SD}+24 \mathrm{~h} \mathrm{CL}+5 \mathrm{SD}$ & $54 \pm 5 \cdot 13$ & $1399 \pm 192$ \\
$30 \mathrm{SD}+24 \mathrm{~h} \mathrm{CL}+5 \mathrm{SD}+24 \mathrm{~h} \mathrm{CL}$ & $137 \pm 16 \cdot 93$ & $5714 \pm 152$ \\
\hline
\end{tabular}

Means of four replicates and standard errors.

T A B LE 4. Ethylene production $\left(\mu \mathrm{m}^{3} \mathrm{mg}^{-1}\right.$ protein over $\left.24 \mathrm{~h}\right)$ by microsomal, soluble and cell wall fractions from leaf laminae of vegetative and induced spinach plants

\begin{tabular}{|c|c|c|c|}
\hline Fraction & $\begin{array}{l}\text { Components added } \\
\text { to the fraction }\end{array}$ & $\begin{array}{l}\text { Vegetative } \\
\text { plants }\end{array}$ & $\begin{array}{l}\text { Induced } \\
\text { plants }\end{array}$ \\
\hline \multirow[t]{3}{*}{ Microsomal } & Buffer & 17 & 13 \\
\hline & 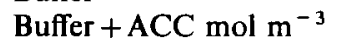 & 178 & 185 \\
\hline & $\begin{array}{l}\text { Buffer + ACC mol m} \\
+\mathrm{MnCl}_{2} 0-5 \mathrm{~mol} \mathrm{~m}^{-3}\end{array}$ & 277 & 292 \\
\hline \multirow[t]{3}{*}{ Soluble } & Buffer & 6 & 4 \\
\hline & Buffer + ACC mol m $\mathrm{m}^{-3}$ & 28 & 19 \\
\hline & $\begin{array}{l}\text { Buffer }+\mathrm{ACC} \mathrm{mol} \mathrm{m} \mathrm{m}^{-3} \\
+\mathrm{MnCl}_{2} 0-5 \mathrm{~mol} \mathrm{~m}^{-3}\end{array}$ & 104 & 112 \\
\hline \multirow[t]{3}{*}{ Cell wall } & Buffer & 19 & 20 \\
\hline & Buffer + ACC mol m${ }^{-3}$ & 177 & 246 \\
\hline & $\begin{array}{l}\text { Buffer + ACC mol m} \\
+\mathrm{MnCl}_{2} 0-5 \mathrm{~mol} \mathrm{~m}^{-3}\end{array}$ & 338 & 428 \\
\hline
\end{tabular}

As expected from literature data (Mayak, Legge, and Thompson, 1981; McRae, Baker, and Thompson, 1982; Lynch, Sridhara, and Thompson, 1985; Kevers and Gaspar, 1985), a microsomal fraction from spinach leaves converted ACC to ethylene in vitro in the presence of manganese (Table 4). Calcium ions up to $1.0 \mathrm{~mol} \mathrm{~m}^{-3}$ appeared uneffective (data not shown) but no difference could be seen in the rates of ACC conversion to ethylene by microsomes between vegetative and induced plants (Table 4). Soluble fractions from both types of plants showed very low and similar capabilities for such a conversion. The cell wall 
fractions from both induced and vegetative plants were seen to convert ACC to ethylene, with a higher activity for those prepared from induced plants. Activity of this fraction was maintained after both a washing in a sucrose gradient and a treatment with $1000 \mathrm{~mol} \mathrm{~m} \mathrm{~m}^{-3}$ $\mathrm{NaCl}$.

\section{DISCUSSION}

For many years, ethylene or ethylene-releasing compounds such as 2-chloroethanephosphonic acid are known to promote flowering of pineapple (Cooke and Randall, 1968; Adriansen, 1976; Zeevaart, 1978). Application of exogenous ethylene is now standard commercial practice for the controlled flowering of pineapple and also of other bromeliads. Besides those in the Bromeliaceae, a few other species have also been found to respond positively to ethylene applications. Ethylene may thus play a role in flowering induction. There are, however, few studies of endogenous ethylene in relation to flowering (Suge, 1977; De Greef et al., 1983). We show here that the transfer of spinach plants from non-inductive to inductive conditions rapidly increases the rate of ethylene production by leaf laminae and also their capacity to convert ACC to ethylene. ACC measurements in laminae indicate a lower concentration within induced plants. This probably corresponds to a faster conversion to ethylene. However, the transfer to continuous light of previously induced plants (mimicked induction) indicates that the changes in ethylene release and $\mathrm{ACC}$-ethylene conversion may not be caused by the onset of flowering since they can be reproduced twice on the same plants. They may be considered rather as a more direct response to photoperiod.

Two cell fractions are able to convert ACC into ethylene in spinach leaves i.e. microsomal and cell wall. Activity of the microsomal fraction is in good agreement with studies indicating that ACC conversion to ethylene is associated with membrane systems (Imaseki and Watanabe, 1978; Mayak et al., 1981; McRae et al., 1982; Lynch et al., 1985). As far as we know, conversion of ACC to ethylene by a cell wall fraction has not been reported until now. However, studies have shown that cell wall digesting enzymes and their cell wall products are capable of stimulating ethylene biosynthesis, and suggest that certain cell wall fragments produced as a consequence of stress may serve as signals eliciting the synthesis of ethylene (Anderson, Matoo, and Lieberman, 1982; Vandermolen, Labavitch, Strand, and DeVay, 1983; Anderson, Chalutz, and Matoo, 1985). This suggests a role for the cell wall in ethylene metabolism. We show that increased capacity of the leaves from induced plants to convert ACC to ethylene is related to an increased capacity of the cell wall fraction.

Although the enzyme responsible for ACC-ethylene conversion has not been isolated, some studies indicate that peroxidases may be considered as a part of the enzyme complex catalysing this step of ethylene metabolism (Yang, Ku, and Pratt, 1967; Rohwer and Mäder, 1981; Vioque, Albi, and Vioque, 1981; Boyer and De Jaegher, 1986). That peroxidases may play a role in ethylene synthesis was suggested by data indicating a relation between ethylene production and membrane binding of peroxidases in vitrifying tissues (Kevers and Gaspar, 1985) and in tissues subjected to stresses, for instance mechanical stress (Boyer et al., 1983). In spinach, it was previously shown that flowering induction is characterized by an increase of the total peroxidase activity and of the acid/basic ratio (Penel and Greppin, 1975). These changes in peroxidases and those reported here for ethylene are very similar to those described in various plant tissues in response to different types of stresses, for instance, mechanical perturbation (Boyer and De Jaegher, 1986) indicating relations between changes in ethylene and in cellular distribution of peroxidases (Gaspar, Penel, Castillo, and Greppin, 1985). This leads us to propose that flowering induction could be considered as a stress response of the plants to a change in their light regime. Results of the mimicked induction are 
in good agreement with this view. Further studies are now needed to determine whether the changes in ethylene biosynthesis described here in spinach plants transferred to continuous light can be related to biochemical (sugar composition, enzyme association) modifications at the cell wall level.

\section{ACKNOWLEDGEMENT}

This work was partly supported by the Swiss Foundation for Scientific Research (Grant no. 3.140-081).

\section{LITERATURE CITED}

AdRIANSEN, E., 1976. Induction of flowering in bromeliads with ethephon. Tidsskrift for Planteavl., 80, 857-68.

Anderson, J. D., Chalutz, E., and Matoo, A. K., 1985. Induction of ethylene biosynthesis by cell wall digesting enzymes. In Cellular and molecular biology of plant stress. Alan R. Liss, Inc. Pp. 263-78.

- MA TOO, A. K., and LieBERMAN, M., 1982. Induction of ethylene biosynthesis in tobacco leaf discs by cell wall digesting enzymes. Biochemical and Biophysical Research Communications, 107, $588-96$.

BERNIER, G., KINET, J. M., and SACHS, R., 1981. Levels, distribution, and metabolism of endogenous substances. In The physiology of flowering. CRC Press, Inc., Boca Raton, Florida. Pp. 135-60.

BOYER, N., and DE JAEGHER, G., 1986. Direct or indirect role of peroxidases in ethylene biosynthesis? In Molecular and physiological aspects of plant peroxidases. Eds H. Greppin, C. Penel and Th. Gaspar. Université de Genève-Centre Botanique publication (in press).

- Desbiez, M. O., Hofinger, M., and Gaspar, Th., 1983. Effect of lithium on thigmomorphogenesis in Bryonia dioica. Ethylene production and sensitivity. Plant Physiology, 72, 522-5.

COOKE, A. R., and RANDALL, D. I., 1968. 2-Haloethanephosphonic acids as ethylene releasing agents for the induction of flowering in pineapple. Nature, 218, 974-5.

De Greef, J. A., van Duck, R., De Proft, M., and Mekers, O., 1983. Flowering maturity and ethylene production capacity of Aechmea victoriana through ACC application. Acta Horticulturae, 137, 211-16.

Gaspar, Th., Penel, C., Castillo, F. J., and Greppin, H., 1985. A two-step control of basic and acidic peroxidases and its significance for growth and development. Physiologia plantarum, 64, 418-23.

Greppin, H., Auderset, G., Bonzon, M., and Penel, C., 1978. Changement d'état membranaire et mécanisme de la floraison. Saussurea, 9, 83-101.

ImASEKI, H., and WaTANABE, A., 1978. Inhibition of ethylene production by osmotic shock. Further evidence for control of ethylene production by membrane. Plant Cell Physiology, 19, 345-8.

Joseph, C., Billot, J., Soudain, P., and Come, D., 1985. The effect of cold, anoxia and ethylene on the flowering ability of buds of Cichorium int ybus. Physiologia plantarum, 65, 146-50.

Karege, F., Penel, C., and GrepPin, H., 1982. Floral induction in spinach leaves by light, temperature and gibberellic acid: use of the photocontrol of basic peroxidase activity as biochemical marker. Zeitschrift für Pflanzenphysiologie, 107, 357-65.

Kasperbauer, M. J., and Hamilton, J. L., 1978. Ethylene regulation of tobacco seedling size, floral induction and subsequent growth and development. Agronomy Journal, 70, 363-6.

KEVERS, C., and GASPAR, TH., 1985. Vitrification of carnation in vitro: changes in ethylene production, ACC level and capacity to convert ACC into ethylene. Plant Cell Tissue Organ Culture, 4, 215-23.

LizADA, C. C., and YANG, S. F., 1979. A simple and sensitive assay for 1-aminocyclopropane-1carboxylic acid. Analytical Biochemistry, 100, 140-5.

LyNCh, D. V., SRIDhara, S., and Thompson, J. E., 1985. Lipoxygenase generated hydroperoxides account for the non-physiological features of ethylene formation from 1-aminocyclopropane-1carboxylic acid by microsomal membranes of carnation. Planta, 164, 122-5.

MCRAE, D. G., BAKER, J. E., and Thompson, J. E., 1982. Evidence for involvement of the superoxide radical in the conversion of 1-aminocyclopropane-1-carboxylic acid to ethylene by pea microsomal membranes. Plant Cell Physiology, 231, 375-83.

MAYAK, S., LeGGe, R. L., and ThOmpson, J. E., 1981. Ethylene formation from 1-aminocyclopropane1-carboxylic acid by microsomal membranes from senescing carnation flowers. Planta, 153, 49-55.

Mekers, O., DE Proft, M., and JACOBS, L., 1983. Prevention of unwanted flowering of ornamental Bromeliaceae by growth regulating chemicals. Acta Horticulturae, 137, 217-23. 
Penel, C., and Greppin, H., 1974. Variation de la photostimulation de l'activité des peroxydases basiques chez l'épinard. Plant Science Letters, 3, 75-80.

1975. The balance between acid and basic peroxidases and its photoperiodic control in spinach leaves. Ibid. 5, 41-5.

ROHWER, F., and MÄDER, M., 1981. The role of peroxidase in ethylene formation from 1aminocyclopropane-1-carboxylic acid. Zeitschrift für Pflanzenphysiologie, 104, 363-72.

SUGE, M., 1974. Nature of the ethylene inhibition of flowering in Pharbitis nil. In Plant growth substances, 1973. Proceedings 2nd International Conference on Plant Growth substances. Hirokowa Publ. Cy. Tokyo. Pp. 960-6.

- 1977. Changes in ethylene production of vernalized plants. Plant Cell Physiology, 18, 1167-71.

Vandermolen, G. E., Labavitch, J. M., Strand, L. L., and DeVay, J. E., 1983. Pathogen-induced vascular gels: ethylene as a host intermediate. Physiologia plantarum, 59, 573-80.

Vioque, A., AlBi, M. A., and VIoque, B., 1981. Role of IAA-oxidase in the formation of ethylene from 1-aminocyclopropane-1-carboxylic acid. Phytochemistry, 20, 1473-5.

YAnG, S. F., Ku, M. S., and PRATt, M. K., 1967. Photochemical production of ethylene from methionine and its analogues in the presence of flavin mononucleotide. Journal of Biological Chemistry, 242, 5274-80.

Zeevanat, J. A. D., 1978. Phytohormones and flower formation. In Phytohormones and related compounds: a comprehensive treatise. Volume II. Eds D. S. Letham, P. B. Goodwin, and T. J. V. Higgins. Elsevier/North-Holland Biomedical Press, Amsterdam. Pp. 291-327. 